Vol. 5 (3), pp. 057-077, July 2015

ISSN: 2276-7789; ICV: 6.05

Copyright $@ 2017$, the copyright of this article is retained by the author(s)

DOI Link: http://doi.org/10.15580/GJER.2015.3.071815098

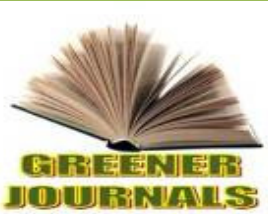

http://gjournals.org/GJER

\title{
Influence of Free Secondary Education Policy on Repetition Rates in Kenya: A Case Study of Kericho County
}

\section{Ngeno Viviline Cherotich, Simatwa Enose M.W. and Ayodo T.M.O.}

\begin{abstract}
Department of Educational Management and Foundations, Maseno University. Department of Educational Management and Foundations, Maseno University. Faculty of Education, Theology and Arts, Kabarak University.
\end{abstract}

Article No.: 071815098

Type: Research

DOI: 10.15580/GJER.2015.3.071815098

Submitted: $18 / 07 / 2015$

Accepted: $20 / 07 / 2015$

Published: $31 / 07 / 2015$

${ }^{*}$ Corresponding Author

Enose M.W. Simatwa

E-mail: simatwae@yahoo.com

\section{Keywords:}

Influence, Free Secondary Education

Policy, Repetition, Kericho County, Kenya
In pursuance of provision of Education for All, Free Secondary Education policy was adopted in 2008 to enhance access, improve quality, equity, relevance and Gender Parity in the provision of secondary school education in Kenya, Kericho County inclusive. The first cycle of students who benefitted from Free Secondary Education policy graduated in 2011. The national Gender Parity Indices from 2004 to 2007 were $\mathbf{0 . 8 9}, \mathbf{0 . 8 9} .0 .89$ and 0.85 respectively while in Kericho County they were $0.75,0.63,0.66$, and 0.71 respectively which were lower than the national. Form to form transition fluctuated as follows 9,103; 9,333; 9,217 and 9,281 in Kericho County meaning that repetition was a concern that required to be addressed. Since Free Secondary Education policy was introduced to address this concern it was important to determine its influence on first cycle of Free Secondary Education funding. Therefore, the purpose of this study was to establish influence of Free Secondary Education Policy on repetition in Kericho County. Objective of the study was to determine the influence of Free Secondary Education policy on repeater rates in Kericho County. The study was based on this concept of investment choices by Pscharapolous and Woodhall (1985), because Free Secondary Education subsidy is an investment choice in Kenya. This study established that Free Secondary Education policy had very low positive influence on repetition with Pearson ( $r$ ) coefficient of 0.04 and $\mathbf{R}^{2}$ of 0.0016 which means it enhanced repetition by $0.16 \%$. The study concluded that Free Secondary Education had very low influence on repetition rates. The study recommended that forced or voluntary repetition should be eradicated as it contributes to wastage in education and militates against the intention of Free Secondary Education policy. The findings of this study are important to stakeholders in secondary education in informing them on the need to review the policy with a view to reducing repetition rates in secondary school education so as to achieve the objectives Free Secondary Education policy. 


\section{INTRODUCTION}

Education is vital in eradicating extreme poverty, reducing child mortality rates, fighting epidemic/pandemic disease such as malaria, Ebola, Tuberculosis Human Immunodeficiency Virus and Acquired Immune Deficiency Syndrome, and developing a global partnership for development. This is supported by world summit declaration on Education for All which is a global movement led by the United Nations Education Scientific and Cultural Organization, which aimed at meeting the learning needs of all children, youth and adults by 2015 (World Bank, 2000a). United Nations Human Regional Commission (2012) points out that education is both a human right in itself and an indispensable means of realizing other human rights. World Bank (2011) states that some countries are now declaring free universal secondary education. In this respect countries like Angola, Benin, Botswana, Uganda and several other sub-
Saharan Africa have introduced Free Secondary Education Policy to be in line with both Education for All Goal and Millennium Development Goals. It is against this backdrop that the Kenya government introduced Free Primary Education and Free Secondary policies in 2003 and 2008 respectively. Free Secondary Education policy was put in place to enhance transition from primary to secondary school by making secondary school education affordable. The objectives of Free Secondary Education policy were to enhance access or transition to secondary education, improve quality, equity, relevance and gender parity in the provision of secondary school education (Ministry of Education, 2007). Currently the government remits Kshs. 28 billion on annually to all public secondary schools to benefit some 2.2 million students and Kshs. 14 billion to public primary schools annually for 10 million pupils. To achieve these objectives the government provided a guideline (Table 1).

Table 1: Costs incurred by the Government for each Student per Year after the Introduction of Free Secondary Education Policy in 2008

\begin{tabular}{lccc}
\hline Vote head & Day Schools (Kshs.) & $\begin{array}{c}\text { Boarding Schools } \\
\text { (Kshs.) }\end{array}$ \\
\cline { 2 - 4 } & $\begin{array}{c}\text { GOK Subsidy } \\
\text { (Free Secondary } \\
\text { Education ) }\end{array}$ & $\begin{array}{c}\text { GOK Subsidy } \\
\text { (Free Secondary } \\
\text { Education ) }\end{array}$ & Parent Fees \\
\hline Tuition & 3,600 & 3,600 & 0 \\
Boarding, Equipment and Stores & 0 & 0 & 13,034 \\
Repair, Maintenance and Improvement & 400 & 400 & 400 \\
Local Travel and Transport & 400 & 400 & 500 \\
Administration Costs & 500 & 500 & 350 \\
Electricity, water and Conservancy & 500 & 500 & 1500 \\
Activity Fees & 600 & 600 & 0 \\
Personal Emolument & 3,965 & 3,935 & 2,743 \\
Medical & 300 & 300 & 100 \\
Total School Fees & $\mathbf{1 0 , 2 6 5}$ & $\mathbf{1 0 , 2 6 5}$ & $\mathbf{1 8 , 6 3 5}$ \\
\hline
\end{tabular}

Source: Ministry of Education (2009)

According to the Ministry of Education (2009) Free Secondary Education is meant to cater for the following items in secondary education: Tuition Kshs. 3,600/=, to cater for the students learning materials for instance textbooks, reams of paper, exercise books and other learning materials, Kshs. 400/= for Repair, Maintenance and Improvement, Kshs. 500/= for Electricity, Water Supply and Conservancy. Kshs. 400/= for Local Transport and Travel, Kshs.500/= Administrative Costs, Kshs.3,965/=, Personal Emolument. Kshs. 600/= and Kshs. $300 /=$ Co-curricular activities and medical care respectively. The day schools parents were to cater for Lunch, Uniforms, personal effects and other projects for example expansion of infrastructure upon approval by the District Education Board in consultation with the Board of Governors and Parents Teachers Association. Clear the fee balance for continuing students for the academic year 2008 (MOE, 2009). The boarding schools on the other hand parents should cater for boarding, Equipments and store Kshs.13, 034/=, Repair, maintenance and improvement Kshs. 400/=, Electricity, water supply and conservancy Kshs. 1,500/= Local Transport and Travel Kshs. $500 /=$ Personal Emolument Kshs. 2,743/= and medical care Kshs. 100/= respectively. Making a total of Kshs. $18,635 /=$. Parents were not required to pay for tuition and co-curricular activities but they were to cater for the following costs school uniforms, boarding and projects (MOE, 2009).

Repetition in schools is a waste of resources to both the parents and the government because the students occupy the space and use resources that would have been used by new entrants. According to UNESCO (2004 a) worldwide, $6.0 \%$ of primary school pupils and $7.8 \%$ of secondary school students repeat a grade annually. In primary schools, repetition rates are highest in West and Central Africa (average repetition rate is 
12.9\%), Eastern and Southern Africa (12.4\%), and Latin America and the Caribbean (10.0\%). In secondary schools, the highest repetition rates are observed in West and Central Africa (18.8\%), the Middle East and North Africa $(12.0 \%)$, and in Eastern and Southern Africa (12.3\%). In East Asia and the Pacific, Eastern Europe and Central Asia, the industrialized countries, and South Asia, not more than $5 \%$ of pupils at the primary or secondary level repeat a grade. A report given by Southern and Eastern African Consortium for Monitoring and Evaluation Quality (2012) indicated that in Zanzibar the repetition rate at secondary school level was $4.9 \%$ per annum. In Kenya repetition was $2.6 \%$ at secondary school level (Onsomu \& Muthaka, 2008). The preliminary survey in Kericho County indicated fluctuations in the students' enrolment as they transited from one form to another. The studies reviewed on the other hand focused on primary and secondary school repetition in general worldwide.
These studies (UNESCO, 2004; SACMEQ, 2012; Onsomu \& Muthaka, 2008) did not address the influence of Free Secondary Education policy on repetition in Kericho County secondary schools for the cohort 2008. This was the knowledge gap this study sought to fill.

\section{Research Objective}

The research objective was: To determine the influence of Free Secondary Education Policy on repetition rates in secondary schools in Kericho County.

\section{SYNTHESIS OF LITERATURE ON REPETITION RATES IN EDUCATIONAL INSTITUTIONS}

UNESCO (2004) revealed in its study the average repetition rates in primary and secondary schools in the world and the results were as shown in Table 2.

Table 2: Average Repetition rates per region, Primary and Secondary School in the world 2001/02

\begin{tabular}{lcc}
\hline Region & \multicolumn{2}{c}{ Repetition rate (\%) } \\
\cline { 2 - 3 } & Primary School & Secondary School \\
\hline East Asia, Pacific & 1.9 & 2.2 \\
Eastern and Southern Africa & 12.4 & 12.3 \\
Eastern Europe, CIS & 1.2 & 1.2 \\
Industrialized countries & 2.1 & 3.9 \\
Latin America, Caribbean & 10.0 & 7.4 \\
Middle East, North Africa & 8.0 & 12.9 \\
South Asia & 4.5 & 5.0 \\
West and Central Africa & 12.9 & 18.8 \\
World & $\mathbf{6 . 0}$ & $\mathbf{7 . 8}$ \\
\hline
\end{tabular}

Data source: UNESCO, Institute for Statistics (UIS) 2004. Global Education Digest 2004. Montreal: UIS.

Regional averages, weighted by each country's population of primary school age, are listed as Table 2. Worldwide, $6.0 \%$ of primary students and $7.8 \%$ of secondary students repeat a grade. In primary school, repetition rates are highest in West and Central Africa (average repetition rate 12.9\%), Eastern and Southern Africa (12.4\%), and Latin America and the Caribbean $(10.0 \%)$. In secondary school, the highest repetition rates are observed in West and Central Africa (18.8\%), the Middle East and North Africa (12.0\%), and in Eastern and Southern Africa (12.3\%). In East Asia and the Pacific, Eastern Europe and Central Asia, the industrialized countries, and South Asia, not more than $5 \%$ of pupils at the primary or secondary level repeat a grade. A comparison of primary school gross and net enrollment rates indicates that there is a high share of late entrants and grade repeaters in Sub-Saharan Africa. Repetition rates in primary and secondary school are listed in the Global Education Digest 2004 from UNESCO. Primary repetition rates are available for 138 countries, secondary repetition rates for 125 countries (UNESCO, 2004). The 15 countries with the highest share of repeaters at the primary level are located in West and Central Africa or Eastern and Southern Africa. The highest primary school repetition rates are observed in Equatorial Guinea (40.5\%), Rwanda (36.1\%) and Gabon (34.4\%). Of the 17 countries with the highest share of repeaters at the secondary level, 15 are in Sub-Saharan Africa and 2 in the Middle East and North Africa. The highest secondary school repetition rates exist in Congo $30.8 \%$, Iraq $27.5 \%$ and Algeria 27.2\% (UNESCO, 2012).

According to Huebler (2010) an analysis of data from a Demographic and Health Survey done in 2001 demonstrates that the vast majority of pupils in primary and secondary school in Liberia are older than the theoretical age for their grade. For example, nearly three quarters of all first-graders in Liberia are at least 3 years older than the official entrance age into primary education. Twenty four percent of all first-graders are 5 or 6 years overage, $14 \%$ are 7 or 8 years overage, and $5 \%$ are 9 or more years overage. Children in the last group start primary school at age 15 or later. According to UNESCO (2006 a) Grade repeaters are more likely to come from families that rank lower on measures of socioeconomic status and related variables (income, parental years of education completed). They also are more likely to be male than female. Subsequently, it occurs more often at grades preceding transitions to middle school, junior high school, or high school than at other grades. Repetition decisions are almost always initiated by the school rather than the parents, although they may be communicated as recommendations rather than requirements (in which 
case, the final decision is left up to the parents). South Africa basic education (2011) carried out a household survey and found that in 2009, on average $9 \%$ of learners enrolled in schools were repeating the grade they were in the previous year. South Africa's level of repetition is high. International comparative information for primary schools for 2007 shows that South Africa's average level of repetition in primary schools at $(7 \%)$, was higher than the average level for developing countries $(5 \%)$ and for developed countries (less than 1\%). In general, repetition is higher among male learners than female learners and much greater in higher grades than in the lower grades.

Musyimi (2011) did a case study on wastage rates in Kenya secondary schools in Kathonzweni district, Makueni County showed that repetition rate for the boys was $1.4 \%$ in form $1,2 \%$ in form $2,4 \%$ in form 3 and $6 \%$ in form 4 while for the girls was $2 \%$ in form 1, $3 \%$ in form 2 , $4 \%$ in form 3 and $7 \%$ in form 4 . Studies further revealed that this repetition rates was caused by poor performance, forced repetition, chronic absenteeism, teenage pregnancies and drug abuse. Okuom, Simatwa, Olel and Wichenje (2012) in their study established high repeater rate of $23.63 \%$ and dropout rate of $20.17 \%$ in Nyando District. Floods and flood related factors were found to be the cause to loss of learning hours and equally exacerbating poverty through destruction of infrastructure and school structures, water borne diseases, high absenteeism, low syllabus coverage and poor performance in flood prone areas of Nyando District. Data was collected using document analysis guide, questionnaire, interview schedule and focus group discussion. This study was done in primary schools.

A study by Macharia, (2013) in Gatanga District, Muranga County found that in the period between 2008 and 2011. Repeater rates greatly increased. It was concluded that the Free Secondary Education policy had contributed negatively to internal efficiency of day schools negatively through increased repeater rates. Questionnaires, interview schedules and document analysis were used to collect data. International Labour Organization (2010) in the study on the micro factors inhibiting education access, retention and completion by children from vulnerable communities in Kwale District, Kenya revealed that the reasons which leads to repetition were absenteeism, pregnancies due to weddings and funerals that take long, human wildlife conflicts, hunger, sickness, distance, beliefs around witchcraft and evil spirits. The studies reviewed were done worldwide and in sub-Saharan countries generally. The one done by Musyimi (2011) did a case study on wastage rates in Kenya secondary schools in Kathonzweni District, Makueni County on repetition rate before the introduction of Free Secondary Education policy. The study done in Nyando District by Okuom et al (2012) was done in primary schools. These studies did not unravel the influence of Free Secondary Education on repeater rates in secondary schools in Kericho County.

\section{CONCEPTUAL FRAMEWORK}

Independent Variable Dependent Variables

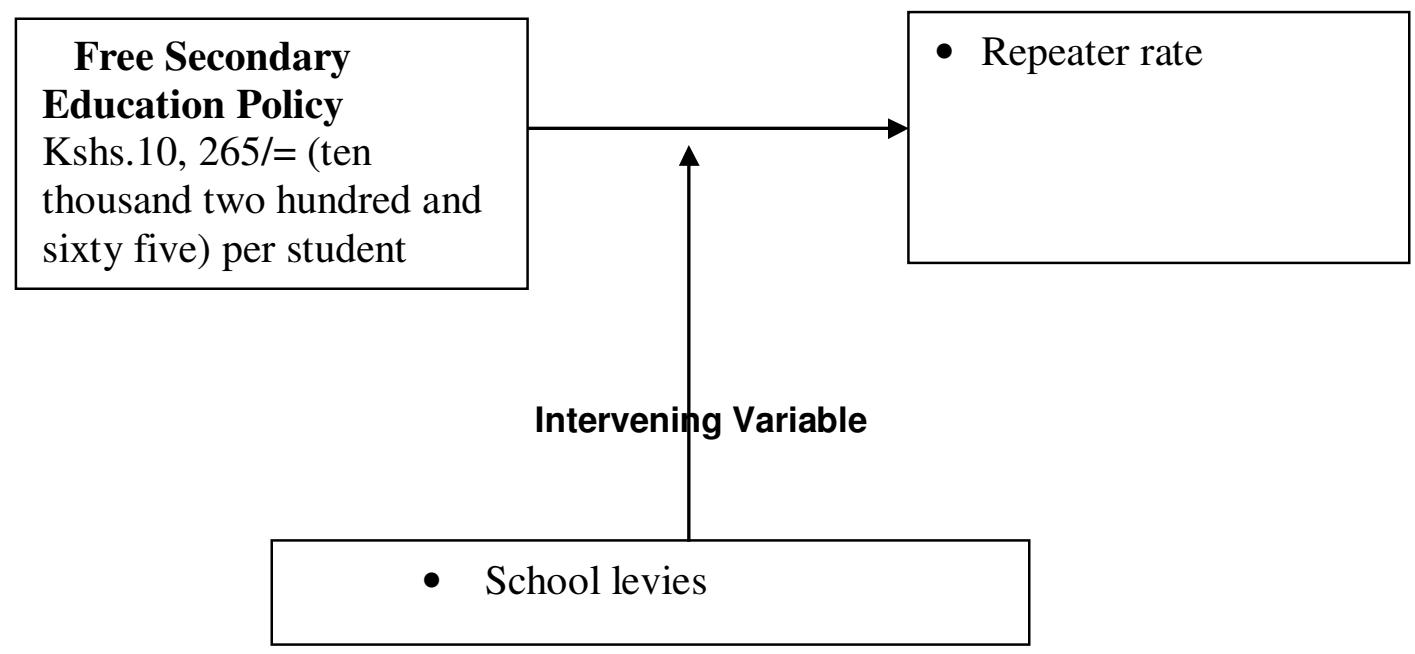

Figure 1: Conceptual Framework Showing the Influence of the Free Secondary Education Policy on Repeater rate and Dropout rate in Kericho County

This conceptual framework helped to focus on independent and dependent variables. Independent variable is Free Secondary Education policy while dependent variables were repeater rate and dropout 
rate. According to Mc Burney and White (2010) an independent variable is selected by the experimenter to determine the effects of behavior while dependent variable is a measure of a subject's behavior that determines independent variables effects. This study focused on the following variables Free Secondary Education Policy and the influence it had on repetition and dropout in Kericho County. The school levies is an intervening variable. This variable was taken care of by including in correlations to establish its influence. The dependent variables were repetition and dropout in Kericho County secondary schools. Gender parity was determined by computing the difference between the boys and the girl before and after Free Secondary Education policy. Two cohorts were used for the study. The first cohort was before Free Secondary Education from 2004 to 2007 this was used as a control group, while the second cohort was after Free Secondary Education policy from 2008 to 2011. The repetition and dropout were computed in Kericho County secondary schools before and after Free Secondary Education policy. Pearson Product Moment Correlation Coefficients and coefficient of determination were used to establish the influence of Free Secondary Education funds on repetition and dropout in Kericho County.

\section{RESEARCH METHODOLOGY}

Descriptive, ex-post facto and correlational research designs were adopted. The study population was 45 Principals, 5 District Quality Assurance and Standard Officers, 45 Directors of Studies and 4,362 form IV students of 2011. The sample size was 400 form IV students, 5 District Quality Assurance and Standard Officers, 40 Directors of Studies and 40 Principals. Snowball and saturated sampling techniques were used to select respondents. Questionnaire, interview schedules, focus group discussion and document analysis guide were used to collect data. Supervisors validated the instruments. Reliability coefficient of the principals' questionnaire was 0.80 at set $p$-value of 0.05 . Quantitative data was analyzed using cohort analysis, descriptive and inferential statistics. Qualitative data was transcribed and analyzed in emergent themes and sub themes. This study established that Free Secondary Education policy had very low positive influence on repetition with Pearson ( $r$ ) coefficient of 0.04 and $R^{2}$ of 0.0016 which means it increased repetition by $0.16 \%$.

\section{RESULTS}

\section{Demographic Characteristics of the Respondents}

The respondents in this study included school Principals, Director of Studies, District Quality Assurance Standards Officer and students as shown in Tables 3 to 4 .

Table 3: Principals' Gender and Headship Experience $(n=40)$

\begin{tabular}{lcc}
\hline Demographic characteristics & $\begin{array}{c}\text { Frequency } \\
(\mathbf{f})\end{array}$ & $\begin{array}{c}\text { Percentage } \\
(\%)\end{array}$ \\
\hline Gender & 30 & 75.00 \\
Male & 10 & 25.00 \\
Female & $\mathbf{4 0}$ & $\mathbf{1 0 0 . 0 0}$ \\
Total & & \\
Headship Experience in years & 1 & 02.50 \\
$1-5$ & 12 & 30.00 \\
6-10 & 17 & 42.50 \\
$11-15$ & 10 & 25.00 \\
$16-20$ & $\mathbf{4 0}$ & $\mathbf{1 0 0 . 0 0}$ \\
Total & & \\
\hline
\end{tabular}

Table 3 provides the demographic characteristics of the respondents. Out of all the $40(100 \%)$ school Principals involved in the study $30(75 \%)$ were male while $10(25 \%)$ were female. This shows that very few female teachers are as appointed school Principals in Kericho County. This is in agreement with the study carried out in a sampled number of schools in Kenya by Bosire et al (2009) where it was indicated that out of the 30 sampled school Principals 22(79\%) were male while 6(21\%) were female. The school principals' leadership experience was also indicated and one $(2.50 \%)$ had headship experience between 1-5 years, $12(30.00 \%)$ had an experience of 6 - 10years, $17(42.50 \%)$ has an experience of $11-15$ years while $10(25.00 \%)$ has an experience of $16-20$ years. From the findings in Table 3 , the school principals had headship experience of 6 years and above. This shows that they had enough experience on management and they were able to give the relevant information on repeater rate and dropout rate in Kericho County. Principals with experience can be relied on for the authenticity of data collected. They were also better placed given that the data required dated back to the year 2004 that required experience in school administration. 
Table 4: Teaching experience before Appointment as School Principals $(n=40)$

\begin{tabular}{ccc}
\hline Years & $\begin{array}{c}\text { Frequency } \\
(\mathbf{f})\end{array}$ & $\begin{array}{c}\text { Percentage } \\
(\%)\end{array}$ \\
\hline $\mathbf{5 - 1 0}$ & 2 & 5.00 \\
$\mathbf{1 1 - 1 5}$ & 5 & 12.50 \\
$\mathbf{1 6 - 2 0}$ & 24 & 60.00 \\
$\mathbf{2 1 - 2 5}$ & 9 & 22.50 \\
\hline
\end{tabular}

Table 4 indicates the school Principals teaching experience before they reached the level of school principal. Those principals with a teaching experience of between $5-10$ years were $2(5 \%)$ between $11-15$ years were $5(12.50 \%)$, while $24(60 \%)$ had a teaching experience between $16-20$ and $9(22.50 \%)$ had a teaching experience of between 21-25 years. This shows that these School Principals had gone through all the ranks in the teaching profession and had experience to be appointed as the school Principals. According to Education Portal (2014) in the US most Principals enter the profession after obtaining enough experience as teachers. This is in agreement with the findings of this study and it shows that the principals were able to answer questions on repeater rate and dropout in Kericho County. This is vital in determining the validity of data that was generated in this study.

Table 5: School Principals' Highest Professional Qualifications $(n=40)$

\begin{tabular}{|c|c|c|}
\hline Highest Qualification & Frequency (f) & Percentage (\%) \\
\hline $\begin{array}{l}\text { BED, BSC +PGDE, BA + PGDE, B.COMM + } \\
\text { PGDE }\end{array}$ & 15 & 37.50 \\
\hline $\begin{array}{l}\text { M.ED } \\
\text { Total }\end{array}$ & $\begin{array}{l}25 \\
40\end{array}$ & $\begin{array}{c}62.50 \\
100.00\end{array}$ \\
\hline
\end{tabular}

Table 5 indicates the education level of the school principals. Fifteen (37.50\%) had a bachelors degree while 25 (62.50\%) had Masters Degree. Basing on the findings in Table 4.4 it is clear that all the Principals had the required level of education. Education Portal (2014) shows that in the US the requirement to be a School
Principals is a Bachelor of Education degree. This is also applicable in this study and in agreement with The Basic Education Act 2013 (Republic of Kenya, 2013). These principals were in a position to understand and give the relevant information on repeater rates and dropout rates in Kericho County, given their academic credentials.

\begin{tabular}{lc}
$\begin{array}{c}\text { Table 6: School Levies incurred by Parents on average in four years before } \\
\text { introduction of Free Secondary Education }\end{array}$ & Policy for the 2004 cohort $(\mathbf{n = 4 0 )}$ \\
\hline Type of School & Amount (Kshs) \\
\hline Days scholars in mixed schools & $63,617.11$ \\
Boarders in mixed schools & $96,954.05$ \\
Girls boarding & $105,299.00$ \\
Boys boarding & $115,234.00$ \\
\hline
\end{tabular}

Table 6 indicates the costs incurred by parents in terms of school fees and levies before Free Secondary Education policy in 2008. The day scholars in mixed schools paid on average Kshs.63, 617.11 in four years while boarders in mixed schools paid Kshs.96, 954.05 in their four years of study. The students in single sex schools paid higher than these other schools. The girls paid Kshs.105, 299 on average while the boys paid Kshs.115, 234 on average for the four years they were in school. This data was important as it assisted to understand the genesis of Free Secondary Education policy on repetition rate and dropout rate. It also helped to justify its inclusion in the study as an intervening variable. 
Table 7: Free Secondary Education Fund and School Levies incurred in four years on average for 2008 Cohort after introduction of Free Secondary Education Policy $(n=40)$

\begin{tabular}{lccccc}
\hline Type of School & $\begin{array}{c}\text { Free Secondary } \\
\text { Education in 4 } \\
\text { year (Kshs.) }\end{array}$ & $\begin{array}{c}\text { Percentage } \\
(\%)\end{array}$ & $\begin{array}{c}\text { Costs incurred by } \\
\text { parents in 4 years } \\
\text { (Kshs.) }\end{array}$ & $\begin{array}{c}\text { Percentage } \\
(\%)\end{array}$ & $\begin{array}{c}\text { Totals in } \\
\text { Kshs. }\end{array}$ \\
\hline $\begin{array}{l}\text { Days scholars in mixed } \\
\text { schools }\end{array}$ & 41,060 & 40.43 & $60,509.65$ & 59.57 & $\mathbf{8 1 , 5 6 9 . 6 5}$ \\
$\begin{array}{l}\text { Boarders in mixed } \\
\text { schools }\end{array}$ & 41,060 & 27.40 & $108,803.85$ & 72.60 & $\mathbf{1 1 2 , 8 6 3 . 8 5}$ \\
Girls boarding & 41,060 & 25.62 & $119,178.57$ & 74.38 & $\mathbf{1 6 0 , 2 3 8 . 5 7}$ \\
Boys boarding & 41,060 & 24.88 & $123,964.43$ & 75.12 & $\mathbf{1 6 5 , 0 2 4 . 4 3}$ \\
\hline
\end{tabular}

Table 7 indicates the costs incurred by the government and the parents after Free Secondary Education policy in Kericho County. The government spent Kshs.41, 060 for four years while the parents spent Kshs.60, 509.65 on average for four years in mixed day schools, and for boarders in mixed schools they spent Kshs.108, 803.85. In girls boarding and boys boarding they spent Kshs.119, 178.57 and Kshs.123, 964.43 respectively Interim guidelines for the implementation of Free Secondary Education (2008) day school students were not given any guideline on the amount of levies the parents were to pay while parents in boarding schools were to pay Kshs.18, 627 per year which would add up to Kshs.74, 508 in four years. Table 7 shows how much the parents paid and it was more than the given figure and parents in day schools paid yet there was no guideline for them. This data was relevant in this study because it helped in establishing the influence of Free Secondary Education policy on repetition rate and dropout rate.

\section{Research Question:}

The research question responded to was: What is the influence of Free Secondary Education policy on secondary school repeater rate in Kericho County?

To establish the influence of Free Secondary Education policy on secondary school Repeater rates data on enrolment was collected for two cohorts 2004 and 2008 before and after Free Secondary Education policy from the school Principals in Kericho County. Grade repeater and cumulative repeater rates were computed in Kericho County. The Grade repeater rate was computed so that the repetition patterns can indicate specific grades for which there is high repetition (UNESCO, $2009 \mathrm{~b}$ ). The cumulative repeater rate was computed to establish the total repeaters for the county and per school. The enrolments obtained were used to compute repeater rates. The results were as shown in Tables 8, 9, 10, 11 and 12 .

\begin{tabular}{|c|c|c|c|c|c|}
\hline Years & & Form I & Form II & Form III & Form IV \\
\hline 2004 & $\begin{array}{l}\mathbf{E} \\
\mathbf{R} \\
\mathbf{N}\end{array}$ & $\begin{array}{c}3603 \\
13 \\
0\end{array}$ & & & \\
\hline 2005 & $\begin{array}{l}\mathbf{E} \\
\mathbf{R} \\
\mathbf{N}\end{array}$ & $\begin{array}{c}3632 \\
14 \\
0\end{array}$ & $\begin{array}{c}3304 \\
27 \\
352\end{array}$ & & \\
\hline 2006 & $\begin{array}{l}\mathbf{E} \\
\mathbf{R} \\
\mathbf{N}\end{array}$ & & $\begin{array}{c}2926 \\
30 \\
352\end{array}$ & $\begin{array}{c}2800 \\
98 \\
619\end{array}$ & \\
\hline 2007 & $\begin{array}{l}\mathbf{E} \\
\mathbf{R} \\
\mathbf{N}\end{array}$ & & & $\begin{array}{c}2829 \\
89 \\
621\end{array}$ & $\begin{array}{c}2308 \\
96 \\
647\end{array}$ \\
\hline 2008 & $\begin{array}{l}\mathbf{E} \\
\mathbf{R} \\
\mathbf{N}\end{array}$ & & & & $\begin{array}{c}2341 \\
113 \\
509\end{array}$ \\
\hline
\end{tabular}


Table 8 indicates the number of repeaters in a class before Free Secondary Education Policy in Kericho County. It was done basing on their enrolments as a cohort and any new students who joined after the admission was left out. Two cohorts were taken so as to capture the students who repeated a class when the rest moved to the next class. This was done by getting the admission numbers and the year they were admitted in the school using the school registers and admission books from form one to form four. According to UNESCO (2009b) repeater rate by grade is by dividing the number of repeaters in a given grade $\mathbf{t}+\mathbf{1}$ by the number of pupils or students from the same cohort enrolled in the same grade in the previous school year $t$. Repetition rate should ideally approach zero percent since high repetition rate indicates poor internal efficiency of education (UNESCO 2009b). For this cohort the students for the cohort from 2004 to 2007 the repeaters were traced by looking at the repeaters in 2005 cohort because these repeaters belong to the 2004 cohort.

\section{Repeater Rates}

The formula used here to determine the repeaters rates by grade was adapted from UNESCO (2009b) education indicators technical guideline.

\section{Formula:}

$$
R R_{i}^{t}=\frac{R_{i}^{t+1}}{E_{i}^{t}}
$$

Where

$R R_{i}^{t} \quad$ Repetition Rate at Grade $i$ in school year $t$.

$R_{i}^{t+1} \quad$ Number of pupils repeating grade $i$ in school year $t$

$E_{i}^{t} \quad$ Number of pupils enrolled in grade $i$, in the school year $t$

The total Repeater rates for the 2004 cohort were further computed in the county and per school. According to
UNESCO (2009 b) cumulative cohort repeater rate can be calculated for the whole level of education by dividing the sum of repeaters in all grades of the given level by the total enrolment of that level of education and multiple by 100. This was adopted in computing the total cohort repeater rate in that county and per school.

In this study the Repeater rates were for the cohort 2004 were computed as follows. The details were as presented in Table 9.

\section{Repeater Rates for the students from form I-IV}

\section{Form one 2004}

$R R_{i}^{t}=\frac{R_{i}^{t+1}}{E_{i}^{t}} \quad=\frac{14}{3603} \times 100=0.39 \%$

\section{Form two 2005}

$R R_{i}^{t}=\frac{R_{i}^{t+2}}{E_{i}^{t}}=\frac{30}{3304} \times 100=0.91 \%$

\section{Form three 2006}

$R R_{i}^{t}=\frac{R_{i}^{t+3}}{E_{i}^{t}}=\frac{89}{2800} \times 100=3.18 \%$

\section{Form Four 2007}

$R R_{i}^{t}=\frac{R_{i}^{t+4}}{E_{i}^{t}} \quad=\frac{113}{2308} \times 100=4.90 \%$

Cumulative repeater rate for the county was computed to determine the total number of students who repeated in the 2004 cohort. The formula by UNESCO, (2009 b):

Cumulative Cohort Repeater Rate $=\frac{R_{i}^{t+1}+R_{i}^{t+2}+R_{i}^{t+3}+R_{i}^{t+4}}{E_{i}^{t}}$ $\mathrm{x} 100$ was used, that is,

$$
\begin{gathered}
=\frac{14+30+89+113}{3603} \times 100 \\
=6.83 \%
\end{gathered}
$$

Table 9: Students Repetition rate in Kericho County before Introduction of Free Secondary Education policy $(n=40)$

\begin{tabular}{cc}
\hline Form & Repetition Rates in Percentages (\%) \\
\hline 1 & 0.39 \\
2 & 0.91 \\
3 & 3.18 \\
4 & 4.90 \\
County Cumulative Repeater rate & 6.80 \\
\hline
\end{tabular}

Table 9 shows the percentage of repeaters before the introduction of Free Secondary Education Policy in 2008. This is a cohort that did not benefit from the Free Secondary Education policy, they joined form one in 2004 and completed in 2007. For Form one 2004 the repeater rates were $0.39 \%$, in 2005 , the repeaters in form 2 were $0.91 \%$ while in form 3 and form 4 they were $3.18 \%$ and $4.90 \%$ respectively. County Cumulative Repeater rate was 6.80 . 
Table 10: Reconstructed Cohort Students Enrolment and Repetition in Kericho County after Introduction of Free Secondary Education policy $(n=40)$

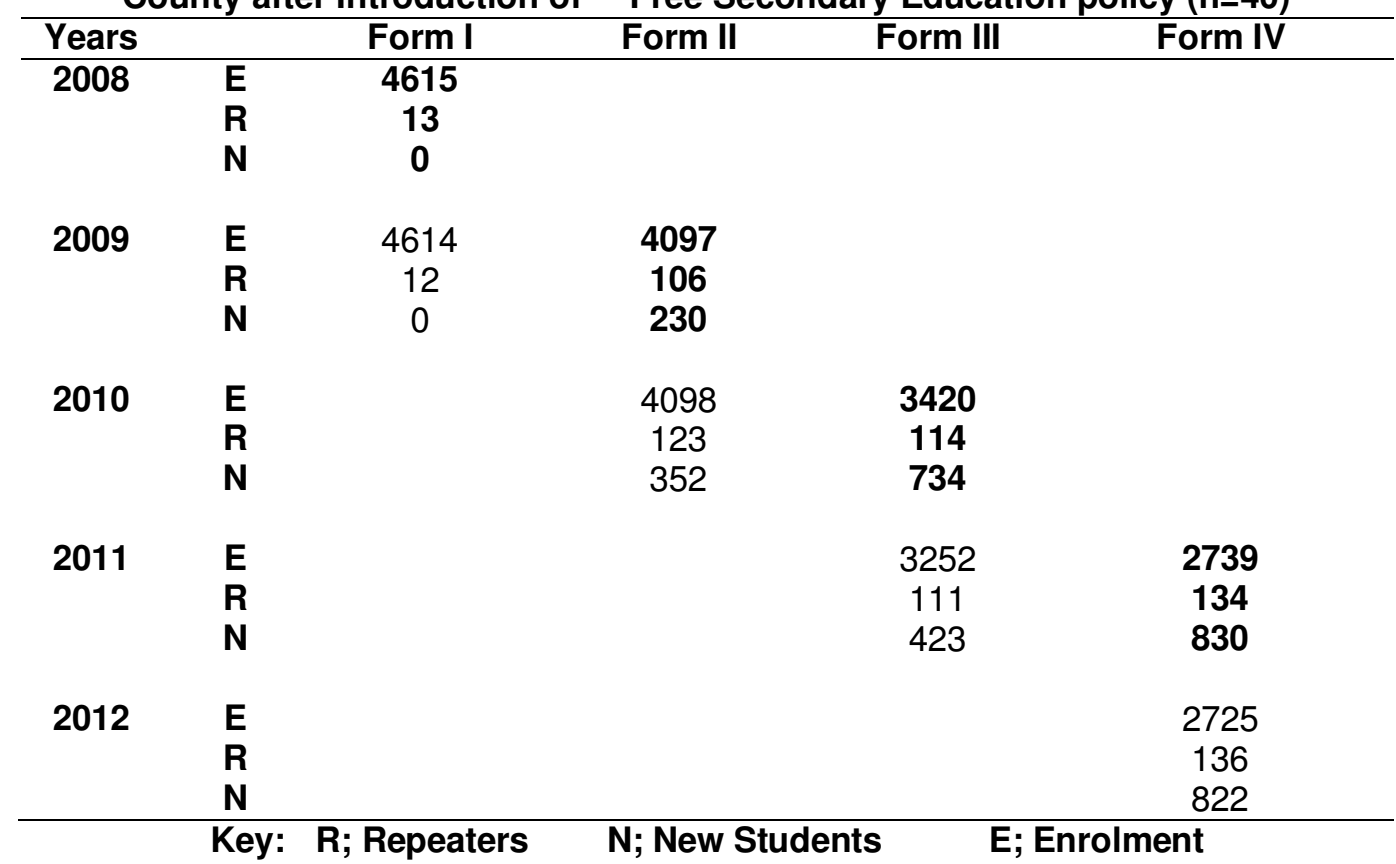

The repeater rates were computed in Kericho County after the introduction of Free Secondary Education policy in the county using the cohort enrolled together leaving out the new students. Two cohorts were used so as to trace the repeaters of that cohort who remained behind as the rest moved to the next class.

Repeater Rates for the students from form I-IV after Free Secondary Education policy

\section{Form one 2004}

$R R_{i}^{t}=\frac{R_{i}^{t+1}}{E_{i}^{t}} \quad=\frac{12}{4615} \times 100=0.26 \%$

Form two 2005

$R R_{i}^{t}=\frac{R_{i}^{t+2}}{E_{i}^{t}}=\frac{123}{4097} \times 100=3.00 \%$

Form three 2006
$R R_{i}^{t}=\frac{R_{i}^{t+3}}{E_{i}^{t}}=\frac{111}{3420} \times 100=3.25 \%$

\section{Form Four 2011}

$R R_{i}^{t}=\frac{R_{i}^{t+4}}{E_{i}^{t}} \quad=\frac{136}{2739} \times 100=4.97 \%$

Cumulative repeater rate for the county was computed to determine the total number of students who repeated in the 2004 cohort. The formula by UNESCO, (2009 b):

Cumulative Cohort Repeater Rate $=\frac{R_{i}^{t+1}+R_{i}^{t+2}+R_{i}^{t+3}+R_{i}^{t+4}}{E_{i}^{t}}$ $\mathrm{x} 100$ was used, that is

$$
\begin{aligned}
& =\frac{12+123+111+136}{4615} \times 100 \\
& =8.28 \%
\end{aligned}
$$

The results were as presented in Table 11.

Table 11: Students Repetition rate in Kericho County after Introduction of Free Secondary Education policy $(n=40)$

\begin{tabular}{cc}
\hline Form & Repetition Rates in Percentages (\%) \\
\hline 1 & 0.26 \\
2 & 3.00 \\
3 & 3.25 \\
4 & 4.97 \\
County cumulative Repeater rate & 8.28 \\
\hline
\end{tabular}


Table 11 shows the percentage of repeaters after the introduction of Free Secondary Education Policy in 2008. This is a cohort that benefited from the Free Secondary Education policy, they joined form one in 2008 and completed in 2011. The aim of Free Secondary Education policy according to the Task Force Report (2007) was to improve on entry and completion in the system. Form one 2008 the grade repeater rate were $0.26 \%$, in form two it was $3.00 \%$ while in form three and four they were $3.25 \%$ and $4.97 \%$ respectively.

Table 12: Comparison of the Repeaters before and after Introduction of Free Secondary Education Policy for the students in Kericho County $(n=40)$

\begin{tabular}{ccc}
\hline Form & $\begin{array}{c}\text { Before } \\
\text { Free Secondary } \\
\text { Education policy }\end{array}$ & $\begin{array}{c}\text { Free Secondary } \\
\text { Education policy }\end{array}$ \\
\hline 1 & 0.39 & 0.26 \\
2 & 0.91 & 3.00 \\
3 & 3.18 & 3.25 \\
4 & 4.90 & 4.97 \\
County Cumulative Repeater Rate & 6.80 & $\mathbf{8 . 2 8}$ \\
\hline
\end{tabular}

Table 12 shows the repeaters before and after the introduction of Free Secondary Education policy. Before Free Secondary Education repetition rates was low but after it went up especially in form two it went up from $0.91 \%$ to $3 \%$ and in for three and four it was $3.18 \%$ and $4.90 \%$ before Free Secondary Education while after it went up to $3.25 \%$ and $4.97 \%$ respectively. County Cumulative Repeater Rate was 6.80 before and 8.28 after introduction of Free Secondary Education policy.

In order to establish the influence of Free Secondary Education policy on repeater rate for 2008 cohort, data on repeater rate, Free Secondary Education fund and school levies per school were computed and the results were as shown in Tables 13, 14, 15, 16, 17 and 18.

According to UNESCO (2009 b) cumulative cohort repeater rate can be calculated for the whole level of education by dividing the sum of repeaters in all grades of the given level by the total enrolment of that level of education and multiplied by 100 . This was adopted to get the cumulative cohort repeater rate per school for the 2008 cohort. The following formula by (UNESCO, 2009 b) was adopted.

Cumulative cohort Repeater Rate $=\frac{R_{i}^{t+1}+R_{i}^{t+2}+R_{i}^{t+3}+R_{i}^{t+4}}{E_{i}^{t}}$ $\mathrm{x} 100$

Table 13: Cumulative Repeater Rates in Kericho County per School after Introduction of Free Secondary Education Policy $(n=40)$

\begin{tabular}{ccc}
\hline Repeater Rates (\%) & Frequency (f) & Percentages (\%) \\
\hline $0.00-9.999$ & 21 & 52.50 \\
$10.00-19.99$ & 9 & 22.50 \\
$20.00-29.99$ & 6 & 15.00 \\
$30.00-39.99$ & 4 & 10.00 \\
$40.00-49.99$ & 1 & 2.50 \\
\hline
\end{tabular}

Table 13 indicates the repeater rates in Kericho County as indicated by the school principals in the 40 schools. Twenty one $(52.50 \%)$ of the schools had repetition ranging from 0.00 to 9.99 , nine $(22.50 \%)$ ranged from
10.00 to 19.99 , six $(15.00 \%)$ ranged from 20.00 to 29.99 , while four $(10.00 \%)$ had repetition ranging from 30.00 to 39.99 . 
Table 14: Free Secondary Education Fund received by Secondary Schools for the 2008 cohort $(n=40)$

\begin{tabular}{ccc}
\hline Amount (KSHS.) & Schools (f) & Percentages (\%) \\
\hline $350,000-759,999.99$ & 12 & 30 \\
$750,000-1,149,999.99$ & 12 & 30 \\
$1,150,000-1,549,999.99$ & 7 & 17.5 \\
$1,550,000-1,949,999.99$ & 2 & 5 \\
$1,950,000-2,349,999.99$ & 3 & 7.5 \\
$2,350,000-2,749,999.99$ & 2 & 5 \\
$2,750,000-3,149,999.99$ & 2 & 5 \\
Total & $\mathbf{4 0}$ & $\mathbf{1 0 0}$ \\
\hline
\end{tabular}

Table 14 indicates the amount of Free Secondary Education funds paid to schools depending on the number of students. Twelve (30\%) of the schools received money ranging from Kshs.350,000 to 749,999.99, another $12(30 \%)$ received Free Secondary Education funds ranging from Kshs.750,000 -1,149,999.99, 7
(17.5\%) received Kshs. $1,150,000$ to $1,549,999.99$, two (5\%) received between Kshs.1,550,000 to $1,949,000$, three $(7.5 \%)$ received between Kshs.1,950,000 to 2,349,999.99, two (5\%) received between Kshs.2,350,000 to 2,749,999.99 while another 2 (5\%) received between Kshs. 2750,000 to $3,149,999.99$.

Table 15: School Levies received by Secondary Schools for the 2008 cohort $(n=40)$

\begin{tabular}{ccc}
\hline Amount (KSHS.) & No. of Schools (f) & Percentages (\%) \\
\hline $00-1,999,999.99$ & 20 & 50 \\
$2,000,000-3,999,999.99$ & 10 & 25 \\
$4,000,000-5,999,999.99$ & 4 & 10 \\
$6,000,000-7,999,999.99$ & 3 & 2.5 \\
$8,000,000-9,999,999.99$ & 1 & 2.5 \\
$10,000,000-11,999,999.99$ & 1 & 2.5 \\
$12,000,000-13,999,999.99$ & 1 & 2.5 \\
\hline
\end{tabular}

Table 15 indicates the school levies received by the schools depending on the number of students. Twenty $(50 \%)$ of the schools received Kshs.1,999,999.99 and below, 10(25\%) received levies ranging from Kshs.2,000,000 -3,999,999.99, four (10\%) received Kshs.4,000,000 to $5,999,999.99$, three $(7.5 \%)$ received between Kshs. $6,000,000$ to $7,999,999.99$, one (2.5\%) received between Kshs.8,000,000 to 9,999,999.99, two $(2.5 \%)$ received between Kshs. $10,000,000$ to $11,999,999.99$ while another one $(2.5 \%)$ received between Kshs. $12,000,000$ to $13,999,999,99$. These were the amount of school levies the schools received for the 2008 cohort from the parents.

\begin{tabular}{|c|c|c|}
\hline Amount (KSHS.) & No. of Schools (f) & Percentages (\%) \\
\hline Below 3,999,999.99 & 23 & 57.50 \\
\hline $4,000,000-7,999,999.99$ & 13 & 32.50 \\
\hline $8,000,000-11,999,999.99$ & 3 & 7.50 \\
\hline $12,000,000-15,999,999.99$ & 0 & 0.00 \\
\hline Above $16,000,000$ & 1 & 2.5 \\
\hline
\end{tabular}

Table 16 indicates the Free Secondary Education fund and school levies received by the schools depending on the number of students. Twenty three $(57.50 \%)$ of the schools received below 3,999,999.99, thirteen (32.50\%) ranged from Kshs. 4,000,000-7,999,999.99, three $(7.50 \%)$ received Kshs. 8, 000,000 to $11,999,999.99$, one
(2.5\%) received above Kshs. 16,000,000. The data was correlated to establish the influence of Free Secondary Education policy on repeater rate in Kericho County. Correlation coefficients $(r)$ were interpreted using Elifson, Runyon and Haber (1990) guideline (Table 17). 
Table 17: Interpretation of Pearson Correlation Coefficients ( $r$ )

\begin{tabular}{lcc}
\hline Strength of the relationship & Positive (+) & Negative (-) \\
\hline Weak/low/small & $0.01-0.30$ & $0.01-0.30$ \\
Moderate/ medium & $0.31-0.70$ & $0.31-0.70$ \\
Strong/high & $0.71-0.99$ & $0.71-0.99$ \\
Perfect relationship & 1.00 & 1.00 \\
No relationship & 0.00 & 0.00 \\
\hline
\end{tabular}

Pearson $(r)$ between + or $-0.01-0.30$ is a weak/low/small relationship, between + or $-0.31-0.70$ is a moderate/medium, while relationship between + or -0.71 -0.99 is a strong/high relationship. Perfect relationship is where it is positive or negative 1.00 while 0.00 means there is no relationship. Coefficient of determination $R^{2}$ is the square of the Pearson $r$ which tells how much of the variance is accounted for by the correlation which is expressed in percentages (Leedy \& Ormrod, 2005). This was adopted in the interpretation of Pearson $(r)$ and coefficient of determination $R^{2}$ in this study.

Table 18: Pearson Product Moment Correlation (r) Matrix for Free Secondary Education fund and Repeater Rate in Kericho County

\begin{tabular}{|c|c|c|c|c|c|}
\hline & & $\begin{array}{l}\text { Free } \\
\text { Secondary } \\
\text { Education } \\
\text { fund }\end{array}$ & $\begin{array}{l}\text { School } \\
\text { levies }\end{array}$ & $\begin{array}{l}\text { Free Secondary } \\
\text { Education fund \& } \\
\text { school levies }\end{array}$ & $\begin{array}{l}\text { Repeater } \\
\text { rate }\end{array}$ \\
\hline \multirow{2}{*}{$\begin{array}{l}\text { Free Secondary } \\
\text { Education fund }\end{array}$} & Pearson Correlation & 1 & .90 & .93 & .04 \\
\hline & $\begin{array}{l}\text { Sig. (2-tailed) } \\
N\end{array}$ & 40 & $\begin{array}{l}.00 \\
40\end{array}$ & $\begin{array}{l}.00 \\
40\end{array}$ & $\begin{array}{l}.80 \\
40\end{array}$ \\
\hline School levies & $\begin{array}{l}\text { Pearson Correlation } \\
\text { Sig. (2-tailed) } \\
\text { N }\end{array}$ & $\begin{array}{l}.89 \\
.00 \\
40\end{array}$ & 40 & $\begin{array}{l}1.0 \\
.00 \\
40\end{array}$ & $\begin{array}{l}.04 \\
.81 \\
40\end{array}$ \\
\hline \multirow[t]{2}{*}{$\begin{array}{l}\text { Free Secondary } \\
\text { Education Fund \& } \\
\text { school levies }\end{array}$} & Pearson Correlation & .93 & 1.0 & 1 & .05 \\
\hline & $\begin{array}{l}\text { Sig. (2-tailed) } \\
N\end{array}$ & $\begin{array}{l}.00 \\
40\end{array}$ & $\begin{array}{l}.00 \\
40\end{array}$ & 40 & $\begin{array}{l}.78 \\
40\end{array}$ \\
\hline Repeater rate & $\begin{array}{l}\text { Pearson Correlation } \\
\text { Sig. (2-tailed) } \\
\text { N }\end{array}$ & $\begin{array}{l}.04 \\
.80 \\
40\end{array}$ & $\begin{array}{l}.04 \\
.81 \\
40\end{array}$ & $\begin{array}{l}.05 \\
.77 \\
40\end{array}$ & 40 \\
\hline
\end{tabular}

Table 18 indicates that Free Secondary Education policy influence on repeater rate was 0.04 . To account for the influence of Free Secondary Education on repeater rate Pearson $r$ was squared. The coefficient of determination $R^{2}=0.0016$ which meant that Free Secondary Education accounted for $0.16 \%$ of the variation in repeater rate. School levies which were an intervening variable had a positive weak of 0.04. Coefficient of determination $R^{2}=$ 0.0016 which meant that Free Secondary Education accounted for $0.16 \%$ of the variation in students repeater rate. When school levies were combined together with Free Secondary Education as Free Secondary Education fund and school levies it had a weak negative influence of
0.05. Coefficient of determination $R^{2}=0.0025$ which meant that school levies accounted for $0.25 \%$ of the variation in students repeater rate. This means that school levies had very little mediating effect, that is 0.0009 which translated to $0.09 \%$ on the influence of Free Secondary Education policy on repeater rates. The other factors could be motorbike business, pregnancies/early marriages, personal effects, Female Genital Mutilation, poverty and discrimination by the parents. This shows that these other factors influence the students' school attendance, performance eventually leading to repetition. 


\section{DISCUSSION}

UNESCO (2009 b) indicated that the repeater rates can be calculated for the whole level of education system by dividing the sum of repeaters in all grades of the given level of education and multiply the result by 100 . While repeater rate by grade is by dividing the number of repeaters in a given grade $\mathbf{t + 1}$ by the number of pupils or students from the same cohort enrolled in the same grade in the previous school year t. Repetition rate should ideally approach zero percent since high repetition rate indicates poor internal efficiency of education (UNESCO, 2009b). This method was very relevant to this study and the repeaters used were those of the same cohort who were left behind when the rest moved to the next classes. This study used the number of students enrolled together in form one as a cohort and left form four together. The repeaters factored in were those left behind when the rest moved to the next classes from 2008 to 2011. To trace these repeaters data for 2009 to 2012 was used. The repeaters were used divided by the number of students enrolled in form one and the same were done for all the classes. This was done for the students in the county after Free Secondary Education Policy in 2008. The following formula was also adapted as given by UNESCO (2009b) and it was expressed in percentages. Free Secondary Education policy did not reduce repeater rate as was intended. These findings agree with studies carried out worldwide by Huebler (2010) who found out that $7.8 \%$ of secondary students repeat a grade. However they do not concur with the findings by UNESCO (2012) which showed that the highest secondary school repeater rates exists elsewhere, that is, Congo (30.80\%), Iraq (27.50\%) and Algeria (27.2\%). In secondary school, the highest repetition rates were observed in West and Central Africa $(18.8 \%)$, the Middle East and North Africa (12.0\%), and in Eastern and Southern Africa (12.3\%). In East Asia and the Pacific, Eastern Europe and Central Asia, the industrialized countries, and South Asia, not more than $5 \%$ of pupils at the primary or secondary level repeat a grade. These findings are also in agreement with those by UNESCO (2006 a) which indicated that grade repeaters are more likely to affect the students in the upper class. It also concurs with the study carried out in South Africa on basic education (2011) which revealed that $9 \%$ of the learners who enroll in school repeat the grade they were in the previous year. The repetition was high on the higher grades than the lower grades. There is also a similarity between this study and that done by UNESCO (2004) which revealed that worldwide $7.8 \%$ of secondary school students repeat a grade. Southern and Eastern African Consortium for Monitoring and Evaluation Quality (2012) showed that in Zanzibar repetition rates stood at $4.9 \%$ per annum while in Kenya it stood at $2.6 \%$ annual according to Onsume and Muthaka (2008). These studies were done annually and it is a general view of repetition while the one in Kericho County was done per grade and overall before and after introduction of Free Secondary Education Policy. It concurs with the study done in Muranga County by Macharia, (2013) which indicated that in the period between 2008 and 2011 repeater rates greatly increased. It also concluded that the Free Secondary Education policy had contributed negatively to internal efficiency of day schools negatively through increased repeater rates.

Since each student receives Kshs. 10,265/= per year this indicates that the higher the number of students the more the money received in a school. This indicates that every school received Free Secondary Education fund at the rate Kshs.10, 265 per year this funds cater for tuition, repair maintenance and improvement, local and travel and transport, administration cost, electricity, water and conservancy, activity fees, personal emolument and medical expenses in order to reduce on repetition. According to Elifson, Runyon and Haber (1990) guideline Correlation coefficients $(r)$ interpretation indicated that this is a weak positive influence. This means that increases in Free Secondary Education funding cause increases in repeater rate. Coefficient of determination $R^{2}$ is the square of the Pearson $r$ which tells how much of the variance is accounted for by the correlation which is expressed in percentages (Leedy \& Ormrod, 2005).

The interview findings revealed that Free Secondary Education policy had not influenced repetition in Kericho County. Students were still repeating based on school ethos and Free Secondary Education policy had no influence at all. During interview with the District Quality Assurance and Standards Officer, it was very evident that repetition was very common in schools. This was due to some many factors despite Free Secondary Education policy being in place. This has made Free Secondary Education fail in its objective of ensuring students are able to access secondary education to enroll and complete. One District Quality Assurance and Standards Officer said, "Every year we have several students who come with complaints that they have been forced to repeat or register for the national examination in another schools because of their performance. This has discouraged many students who had the intentions of completing secondary education, on time". This is as indication that schools still repeat students meaning Free Secondary Education has not help in reducing repetition but there could be other underlying factors leading to wastage. The Directors of Studies were also interviewed concerning the influence of Free Secondary Education policy on repetition. Most of the Directors of Studies revealed that repetition was still very common in their schools despite Free Secondary Education policy being in place. In fact one of them said, "we have students who repeat when the parents demanded or on their own because they want better grades to enable them do" superior courses at university level this shows that the students and parents also contributes to repetition rates in the county. There was also another Director of Studies who said, "we have come up with a policy to try and ensure the learners work hard and we encourage them to get a $\mathrm{C}$ minus so that they can move to the next class. Any student who gets below this grade automatically repeats a class because they have not attained the required mean score." This shows that performance has 
great influence repetition in these schools. Another Director of Studies revealed that, "some of these students disappear from school due to other reasons and when they report back to school they have lost a lot making them repeat to catch up. In these schools Free Secondary Education policy has little influence on repetition because of other reasons a part from these funds."

During the focus group discussion with the students they felt that repetition was made almost compulsory for them during their time. In fact one of the students said, "Despite Free Secondary Education policy being in place we were still forced to repeat if we had grades below what was set by the school". This shows that the schools administrators and parents contributes to repetition in schools making it had for Free Secondary Education policy objectives to be achieved. Despite Free Secondary Education policy, this study established that there were other underlying factors that were negating the influence of Free Secondary Education policy on repetition, since Free Secondary Education policy was meant to eradicate repetition. All the District Quality Assurance and Standard Officers, Director of Studies and Students during focus group discussion and interview confirmed that repetition was still practiced in the schools despite all the measures by the government. They further explained that schools are struggling with performance forgetting the fact that students should go through the system so that education can be internally efficient. Some of the Director of Studies especially from single sex schools revealed that students repeater in their schools. In fact one of the Directors of Studies said, " Free Secondary Education policy has not reduced repetition in any way because currently more students are repeating. This is because there are other factors that contribute to these apart from Free Secondary Education fund being in place". They further gave the following reasons that had contributed to repetition in the county through interview and focus group discussion. They indicated that motor bike business was the main contributor of repetition since most student do the business during their free time and holidays hence leading to poor performance due to lack of concentration. A director of studies strongly said, "The parents are to blame for the motor bike influence on their children since some of them find that this is a source of income to the family hence they allow the boys to engage in it making them not to do well in school because of lack of concentration in class". This leads to being forced to repeat.

The girls were also affected but by the motor bike business men who enticed them with money so as they can engage in sexual activities leading to pregnancy and early marriage. This leads them to repeat if they come back to school because of lack of consistency. The other reason that was mentioned largely by all the District Quality Assurance and Standard Officers, Director of Studies and Students in focus group discussion was poor performance leading to forceful repetition especially in single sex boarding schools where the students are forced to repeat by the teachers so that their school could be in a good position when they do Kenya Certificate of Secondary Education Examinations. In fact one of the District Quality Assurance and Standard Officer said, "Performance has played a big role because the parents and the teachers ensure that if the children do not perform well they are forced to repeat so that they can do better and also to ensure the school mean is high". The Director of Studies and students also mentioned largely that the issue of performance had affected the repetition rates in the county despite the introduction of Free Secondary Education policy which was meant to counter it. A student mentioned that their schools they have devised ways of making the students repeat despite the government policy against it. The student said, "Whenever some students perform below the school standard their parents are called to sign in form two that if they do not meet the target in form three they should repeat leaving them with no option but repeat form three or form two because they will affect the school means score." There was also another student who said," When we did not perform well in class our parents are called and asked to take us to another schools or sign a form stating that they want their child to repeat and the student is given a similar form to sign. This leaves us with no option but to repeat suggesting that fees were no longer a big burden as Free Secondary Education was in place". This shows that school in the county still make their students repeat despite the government policy that the children should be allowed to proceed to avoid wastage due to high repetition rates in form three and form four. This seems to happen because the schools want their schools to excel as compared to the other schools. This is in agreement with the findings by Musyimi (2011) in Makueni County which revealed that repetition was caused by poor performance and forced repetition.

School levies despite Free Secondary Education policy was also indicated by all the Director of Studies and largely by the students as a factor influencing repetition. The students believe that it has led to their repetition since every time they are sent home they miss out on syllabus coverage; this makes them perform poorly leading to repetition. In fact one of the students during focused group discussion said, "We were always sent home in spite Free Secondary Education policy being in place to get money during the term and we end up losing a lot in class leading to some of us repeating." School levies is one of the major contributors of repetition. For instance Free Secondary Education policy caters for only $40.43 \%$ of the required levies by the day scholars while parents cater for $59.57 \%$. Parents with children who are boarders in mixed school cater for $72.60 \%$ while government pays $27.40 \%$. For the single sex schools the girls and the boys' schools the government caters for $25.62 \%$ and $24.88 \%$, while the parents cater for $74.38 \%$ and $75.12 \%$ for girls' and boys' schools respectively (Table 4.6). This finding is in agreement with the studies done by ILO (2010) in Kwale District which revealed that one of the reasons which influence repetition was lack of funds.

Indiscipline is also another factor that was indicated largely by all the District Quality Assurance and 
Standard Officers and Directors of Studies when they were interviewed. They believed that since students were sent home for disciplinary cases especially the boys they missed a lot leading to poor performance and finally repetition. During the students' focus group discussion a student said, "Indiscipline led to repetition since those students who were not disciplined were always sent home because of mistakes and they also lack concentration in class leading to repetition". This is an indication that indiscipline played a role in influencing repetition despite Free Secondary Education policy being in place. Students transfer from school to school despite Free Secondary Education policy, was mentioned by all the District Quality Assurance and Standard Officers and Director of studies during the interview that it has also led to repetition. The students also during their focus group discussion mentioned that the students who come from different schools always come and repeat a class in their schools. A Director of Studies explained that, "Some parents kept transferring their children from one school to another and it affected the continuity of the child in terms of syllabus coverage because schools are not at par when it comes to the syllabus coverage". This shows that transfer has an influence on repetition in secondary schools, because as the students struggle to fit in their new schools some repeat in the process.

Pregnancy and boy/girl relationship was also mentioned as influencing repetition especially in day schools. All the District Quality Assurance and Standard Officer, groups of students and Director of Studies all mentioned that it has influenced repetition in secondary schools because out of these relationships the girls are the ones who face the consequences. In fact one of the Director of Studies said, "the students who engage in boy/girl relationship always lack concentration in class leading to poor performance. Others get pregnant making most girls drop out and when they get back to school they repeat their former classes". The District Quality Assurance and Standard Officer and the students gave the same factor as influencing the girls' education more than the boys. This is in agreement with the findings by Musyimi (2011) in Makueni County which revealed that repetition was caused by teenage pregnancies. This is in agreement with the studies done by ILO (2010) in Kwale District which revealed that reasons for reasons which leads to repetition was pregnancies due to weddings and funerals that take long. Family responsibilities were indicated by all the District Quality Assurance and Standard Officer, Director of Studies and students during interview and focus group discussion pointed out largely as one of the factors affecting the girls. This makes them absent from school missing out on the syllabus coverage and makes them not perform well in class like their colleagues who are in school the whole time. Due to this most of the girls are forced to repeat to learn what they had missed out. For instance a Director of Studies said, "When a family member is sick especially a parent the girls take up the family responsibilities. The girls are asked to take care of the sick and also provide for the entire family making them not perform well in school leading repetition this is common in day schools". This finding is in agreement with the findings of studies done by ILO (2010) in Kwale District which revealed that reasons which leads to repetition was domestic work which has led them not to perform well in their academic work.

Drug abuse was also mentioned by all the Director of Studies and District Quality Assurance and Standard Officers as affecting the students especially the boys and a few girls. This mainly affects the boys' performance in school making them repeat a class because of this poor performance which negates the purpose of Free Secondary Education policy. The Director of Studies talked of quite a number of boys who were sent home in form three and four because of drug abuse. This explains why the repetition is high in the upper class especially among the boys. In fact one of the Director of Studies in one of the schools said, "I was a class teacher in one of the classes in that cohort and I had students who were struggling with drug abuse and they had not been performing well leading to them repeating." This is in agreement with the findings by Musyimi (2011) in Makueni County which revealed that repetition was caused drug abuse. Students' attitude towards their studies has influenced repetition in spite of Free Secondary Education policy due to poor performance in school. This was mentioned by the entire District Quality Assurance and Standard Officer and Director of Studies during interview. Attitude made the students to hate school, some even their teachers and eventually because of these it led to poor performance and finally repetition despite Free Secondary Education policy. This came up clearly also during the students focused group discussion. One of the District Quality Assurance and Standard Officer said, Attitude influenced both the boys and the girls in secondary schools despite Free Secondary Education policy whereby they tend to develop a negative attitude towards certain subjects affecting their overall grades hence poor performance leading to repetition. We have always tried to discourage repetition but there are still a number of schools who do it

against the regulations. This is in agreement with the findings by Musyimi (2011) in Makueni County which revealed that repetition was caused students attitude.

Absenteeism was also mentioned by all the Director of Studies and students as one of the factors leading to repetition. This is was common during the beginning of the term whereby some students do not come to school so as to avoid entry examinations. This makes them perform poorly at the end of the term. A director of studies from one of the boys' school said, "in spite of Free Secondary Education policy the boys did not come to school at the beginning of the term because they had not prepared for the entry exam and this made some of them perform poorly at the end of the year leading to repetition." This shows that there were students who deliberately stayed away from school making them perform poorly. This was due to lack of preparation on the side of the students during their holidays. This is in agreement with the findings by Musyimi (2011) in 
Makueni County which revealed that repetition was caused by chronic absenteeism. This is in agreement with the studies done by ILO (2010) in Kwale District which revealed that one of the reasons which lead to repetition was absenteeism.

Sickness was also another factor that has led to repetition despite Free Secondary Education policy being in place. This was mentioned by all the Director of Studies and students during the interview and focus group discussion respectively. They mentioned that there are students who have been sick most days of the term making them miss out on syllabus coverage, with time these students repeat because they are not at par with the rest of the class. This finding concur the study done in western Kenya by Achoka (2007) which revealed that HIV/AIDS influence wastage. This finding is in agreement with the studies done by ILO (2010) in Kwale District which revealed that reasons which lead to repetition were sickness. The other factor mentioned by some students was lack of school uniform, books and inadequate teachers. These factors do not contribute much to repetition in Kericho County. The interview and focus group discussion findings were crucial in this study as they helped to verify the correlation output which indicated that Free Secondary Education policy had very low influence on repeater rates. Thus they indicated that there were other factors that highly influenced repetition of students. These factors included; students attitude, sickness, poor academic performance, school policy on academic performance and motor bike business. These factors seem to have had stronger influence than Free Secondary Education policy on repetition of students.

It is important to note that education, children and security are inseparable variables in society.

Children grow up in several environments. Home, school and community are the settings for social and intellectual experiences from which they acquire and develop the skills, attitudes and attachments which characterizes them as individuals and shape their choice and performance of adult roles.

\section{CONCLUSION}

Free Secondary Education policy had little positive influence on repetition in Kericho County and accounted for only $0.16 \%$ increase of repeater rate. Interview findings further revealed that Free Secondary Education policy did not have much influence on repetition rates.

\section{RECOMMENDATIONS}

In view of the finding that Free Secondary Education policy had a weak positive influence on repeater rates, since it accounted for $0.16 \%$ of the variation and other factors such as poor academic achievement, student absenteeism, school fees/levies, forced repetition, indiscipline accounted for $99.84 \%$ the study recommended that:

i) The government policy that; no child should be forced to repeat a class should be enforced. This would reduce cases of repetition in schools as it does not add value but only increases wastage rate and reduces internal efficiency of schools.

ii) Academic guidance and counseling be strengthened in schools so that students can easily transit from one class to another. This would curb repetition rates in schools in the county.

iii) Principals and parents should work hand in hand to ensure that students report to schools on time and stay in the school throughout the term. This would help the students to concentrate on their studies and develop qualities of successful students thereby performing well and being disciplined with the consequences that repetition due to poor performance is void.

\section{REFERENCES}

Achoka JSK (2007). In Search of Remedy to Secondary School Dropout Pandemics in Kenya. Role of the Principal. Educational Research and Review. Vol. 2 (7): 236-244.

Adeyemi TM (2012). School Variables and Internally Efficiency of secondary schools in Ondo State, Nigeria. Journal of Educational and Social Research. Vol.2(3): ISSN 2240-0524.

Ambayo A A (1997). Parental, Social-economic Status and its Influence in Standard One Enrolment in Primary Schools. A Case study of Migori District. M.ED Thesis, Kenyatta University.

Arnot M (2010). RECOUP Working Paper No. 26. Youth Citizenship, National Unity and Poverty alleviation: East and West African approaches to the education of a new generation. Cambridge. University of Cambridge Press.

Asia Society. (2014). National Assessment of Equity in American Schools. www.quickanded.com/.../promoting-equity-stateby-state-school-by-school.

Basic Education Report. (2010). Educational Measurement, Assessment and Public Examination. Report on the National Certificate of Examination Results. Republic of South Africa; Government printer.

Best J W \& Kahn J V (1998). Research in Education. Allyn and Bacon. Boston.

Best J W (1977). Research in Education. New Jersey. Prentice Hall.

BBC. (2008). Free Secondary Schools for Kenya. London: BBC News Africa. News.bbc.co.uk/2/hi/Africa/7239577.stm. Retrieved on $17^{\text {th }} 2012$, at $1: 45 \mathrm{pm}$. 
Bii N \& Nzevi J (2013). Internal Efficiency and Performance: An Assessment of Secondary Schools in Bureti District, Kenya. Journal of Africa Studies in Educational Management and Leadership Vol. 3:5-18. www.kaeam.or.ke/.../international-efficiencyand-performance-an-assess.

Bosire J, Sang A K, Kiumi J K \& Mungai V C (2009). The Relationship between Principals' Managerial Approaches and Student Discipline in Secondary Schools in Kenya. An International MultiDisciplinary Journal, Ethiopia.

Castle L B (1966). Growing up in East Africa. London: Oxford University Press.

Chabari E (2010). Challenges Facing Effective Implementation of Free Secondary Education in Public Secondary Schools in Kangundo District, Kenya. Unpublished M.ED Thesis. Chuka University College.

Coclough, C \& Keith M I (1993). Educating all the Children: Strategies for primary Schooling in the South. New York: Longman Publishers.

Cohen L \& Manion L (1992). Research Methods in Education. London: Routledge: Oxford University Press.

Comboni Missionaries Kenya. (2012). Turkana Zone Charter Diocese of Lodwar (dol). Webmaster: Francisco Carrera.

Creswell J W (2009). Research Design, Qualitative, Quantitative and Mixed Methods Approaches. California SAGE Publications.

Draves WA (nd). Why boys under-perform in school. Information that works .http://www. williamdraves.com/works/boys.htm.

Elifson K W, Runyon R P \& Haber A (1990). Fundamental of Social Statistics. MC Graw Hill. Newyork.

Gachugi J M C (2011). Factors Contributing to Educational wastage in Public and Private secondary Schools in Municipality Division, Nyeri District, Central province, Kenya. Unpublished M.ED Thesis, Kenyatta University.

Gall D M, Gall J P \& Borg R W (2007). Educational research, an introduction. New York: Longman.

Gathigah M (2014). Student Dropout Rate on the Increase Despite Free Education. Journalism and communication for Global Change. Nairobi. IPS. http://www.ipsnews.net/2010/12/student-dropout-rate-on-the-increase-despite- freeeducation/highest-population-of-illiterate-adultsUnesc.html.

Gay L R (1987). Educational Research: Competences for Analysis and Application. Florida International University: Merrill Publishing Company.

Grey B (2008). High school drop-out rate in major US cities at nearly 50 percent. ICFI. New York City: Oxford University Press.
Hallack P \& Poisson M. (2007). Corrupt Schools, Corrupt University: What can be done? Paris: IIEP UNESCO.

Harbison R W \& Hanushek, E. (1992). Educational Performance of the Poor: Lessons from Rural Northeast Brazil. New York: Oxford University Press.

Holsinger DB, Jacob J W \& Migumu B C (2002). Cost Effectiveness Analysis of secondary schools in Uganda: comparison of Government and Private Schools. Brigham: Kennedy Centre for International Studies of Brigham Young University.

Huebler F (2010). International Education Statistics. Adult and youth literacy in 2010 Paris: UNESCO Institute for Statistics (UIS). Retrieved on Sunday $24 / 06 / 2014$ at $7: 45 \mathrm{pm}$.

ILO. (2010). Micro factors inhibiting Education access, Retention and completion by children from vulnerable communities in Kenya. Kenya Out of School Report.

Katharina V (2013). Education Position Paper improving learning, expanding opportunities international development. https://www.gov.uk/EducationPositionPaperJuly 2013.

Kathuri N J \& Pals D A (2005). Introduction to Educational Research. Education sector Development. Vol. 14 (3). Nakuru. Education Media.

KENPRO. (2013). Challenges Facing the Implementation of Free Primary School in Kenya. Kenya Project Organization. http://www.kenpro.org/papers/htm.

Kenya Education Partnerships. (2010). Factors Affecting Quality Education in Kenya schools in ASAL areas. Friends of Kenya.

KNEC.(2010). KCSE Results 2011. Nairobi: Kenya National Examination Council. http://blog.theonlinekenyan.com/kcse-results2009.

KNEC. (2011). KCSE Results 2011.Nairobi: Kenya National Examination Council http://blog.theonlinekenyan.com/kcse-results2010.

KNEC. (2012). KCSE Results 2011. Nairobi: Kenya National Examination Council http://blog.theonlinekenyan.com/kcse-results2011.

Koross PK, Ngware W M, \& Sang A K (2009). "Principals' and Students' Perceptions on Parental Contribution to Financial Management in Secondary Schools in Kenya", Quality Assurance in Education. Emerald Insight Journal. Vol. 17 (1): 61-78.

Leedy P D \& Ormrod J E (2005). Practical Research: Planning and design. New Jersey: Pearson Merrill Prentice Hall.

Macgregor, K. (2007). South Africa: Student drop-out rate 
.alarminghttp://www.universityworldnews.com/ar ticle.php?story=200710251 02245380.

Macgregor K (2012). South Africa: Student drop-out rates.

http://learningenglish.voanews.com/content/high -dropout-rate-a-problem-for-south-africa144393775/606824.html.

Macharia R W (2013). Impact of FSE Policy on Internal Efficiency of Day Schools in Gatanga District, Murang'a County, Kenya. Nairobi. Kenyatta University.

Mayo J \& Murambi N K (2009). The impact of Cost Sharing on Internal Efficiency of Public Secondary Schools in Ndivisi Division, Bungoma District. Mediterranean Journal of Social Science. Vol.4 No.13 441. Retrieved on 11:50 am on $6^{\mathrm{TH}}$ April 2013.

Mc Burney D H \& White T L (2010). Research Methods. Wadsworth Cengage learning. United States of America.

Mikiko N, Yamano T \& Sasaoka Y (2005). Impacts on the universal primary education attainment and private costs in rural Uganda. Tokyo: National Graduate Institute for policy studies. http://www3.grips.ac.jp/ yamanota/UgandaUPE $\% 200 c t \% 202005$.pdf

MOE. (2007). Report of Task force on Affordable Secondary Education. Nairobi. Ministry of Education.

MOE. (2008 a). Endangering Education Sector Budget. Reforming Future Education Sector Budgets .Nairobi: Government Printer.

MOE. (2008 b). The Development of Education National Report of Kenya. Inclusive education: The Way of the Future. The International Conference on Education, Geneva, 25-28 November 2008.

MOE. (2009). Guideline for the Implementation of Free Secondary Education. Republic of Kenya. Nairobi.

MOE. (2011). Quality education for National Development. Nairobi. Government Printer.

MOE. (2012). Education for Development. Kericho District Education Day. Prepared by DEO's Office Kericho.

MOE. (2013). Kipkelion District Education Day. Prepared by DEO's Office Kipkelion.

Muchiri K (2012). Challenges Facing Implementation of FSE in Kangemi District. Muranga County. Unpublished M.ED Thesis. Kenyatta University.

Mugenda O M \& Mugenda A G (2003). Research Methods: Quantitative and Qualitative Approaches. Nairobi: ACTS Press.

Muindi M (2012). Impact of FSE Policy on Quality of Secondary Education in Ketanyi Division. Yatta district, Machakos County. Unpublished M.Ed. Thesis. Kenyatta University.

Mulama J (2004). Education-Kenya: Too Much, Too Soon? Nairobi: Press Service.
Mundia L (nd). Secondary School wastage, Continuing Education and Youth Unemployment in Zambia. http://www.directions.usp.ac.fj/collect/direct/inde x/assoc/D770108.dir/doc.pdf

Murunga F, Kilaha K, \& Wanyonyi F (2013). Emerging Issues in Secondary School Education in Kenya. International Journal of Advanced research. Vol. 1. Issue 3

Musyimi C M (2011). Wastage Rates in Kenyan Secondary Schools. A case study of Kathonzeni District, Makueni County. Kenyatta University Institutional Repository. http://ir library.ku.ac.ke/handle/123456789/7290.

Mwebi B \& Simatwa E M W (2013). Expansion of Private Universities in Kenya and its Implication on Quality and Completion Rate: An analytical Study. International Research Journals. Vol. 4 (4): 352-366 http://www.interesjournals.org/ER.

Mwiria K (1985). The harambee School Movement in Kenya. A historical perspective PhD Dissertation, Standford University.

Nanda P K (2014). India has the highest population of illiterate adults. Live Mint \& Wall Street Journal: http://www.livemint.com/Politics/3yYYIDoiLTWDi JAOg5J9SL/India-has-the- highest-populationof-illiterate-adults-Unesc.html.

NCES. (2007). Achievement Gaps: How Hispanic and White Students in Public Schools Perform in Maths and Reading on the National Assessment of Educational Progress. http://nces.ed.gov/nationsreportcard/pubs/studie s/2011459.asp.

NCES. (2011). Trends in High School Dropout and Completion Rates in the United States: National Assessment of Educational Progress U.S: Department of Education. https://nces.ed.gov/pubs2012/2012006.pdf.

NCPA. (2008). The High School Dropout's Economic Ripple Effect. National Centre for Policy Analysis.ldeas changing the world. http://www.ncpa.org/sub/dpd/index.php?

Ngeno V C, Simatwa, E M W \& Soi D C (2013). Determinants of Girl Students' Academic Achievement in Mixed Day and Boarding Secondary Schools in Kericho District: An Analytical Study. Educational Research Journal.Vol. $\quad 4 \quad$ (7):543-554. http://www.interesjournals.org/er/.

Ngeno V C, Simatwa E MW \& Ayodo T M O (2012). Cost Effectiveness Analysis of Educating Girls in Mixed Day and Boarding Secondary Schools in Kenya: A Case Study of Kericho District. Educational Research Journal. Vol. 3(5): 480494. http://www.interesjournals.org/ER.

Ngesu L, Wachira L, Mwelu B \& Nyabisi E (2012). Critical Determinants of poor performance in KCSE among Girls in Arid and Semi Arid. Journal 
of African Studies in Management and leadership. Volume 1 (2): $\quad 63-70$ http://www.kaeam.or.ke/articles/Vol2N/Paper6.p df.

Ngware M, Onsumu E, Muthaka F \& Muthika D. (2006).Improving Access to secondary Education in Kenya. What can be done? Emerald Journal. Vol. 25 (7): 448 www.emeraldinsight.com. Last visited $12^{\text {th }}$ May, 2013.

Nyamesa A M \& Chemwai B (2013). Drop out among pupils in rural primary schools in Kenya. The Case of Nandi North District, Kenya. Journal of Education and Practice Vol.4,(19).

OECD. (1975). Education Equality and life. Volume 1. Paris. Organization for Economic Co-operation and Development.

OECD. (2000). Teacher Utilization in Developing Countries. Paris. Organization for Economic Cooperation and Development .

OECD. Development Centre (2010). Gender Inequality and the Millennium Development Goals: What are the Missing Dimensions? (231 - 240) Issues Brief. Paris. Organization for Economic Co-operation and Development .

Oketch M \& Somerset, A. (2012). A Free Primary Education and After in Kenya: Enrolment impact, quality effects, and the transition to secondary school. Consortium for Research on Educational Access, Transitions and Equity. Create Pathways to Access Research Monograph No.37: http://www.createrpc.org/pdf_documents/PTA37.pdf.

Okuom HA, Simatwa EMW, Olel MA \& Wichenje K M (2012). Assessment of Factors that Contribute to Repetition and Dropout of Pupils In Primary Schools in Flood Prone Areas of Nyando District, Kenya: An analytical study. Educational Research Vol. 3(2): 190201 http://www.interesjournals.org/ER.

Onsomu E N \& Muthaka D (2008). Financing of Secondary Education in Kenya. Costs and Options. Nairobi: Kippra.

Owolabi J (2006). Quantitative Methods of Educational Planning. Moborode: Lucky Odoni (Nig.) Enterprises.

Paul K (2008). An Assessment on the impact and Sustainability of FPE in Migwani Division. Kitui County. London. Oxford University.

Pierrakeas C \& Xenos M (2009). A Comparative Study of Dropout Rates and Causes for Two Different Distance Education Courses Hellenic Open University .Greece

Psacharapoulos G \& Woodhall M (1985). Education for development. An analysis of investment choices. Washington D.C: Oxford University Press.

Punch K F (2005). Introduction to Social Research: Quantitative and qualitative approaches. London. SAGE Publications Ltd.
Republic of Kenya. (1988). Sessional Paper No.6 of 1988 of Education and Manpower Training for the next decade and Beyond. Nairobi: Government Printer.

Republic of Kenya. (2004). Sessional paper No. 1. of 2004 A policy framework for Education, Training and Research. Nairobi: Government Printer.

Republic of Kenya. (2005). Kericho District Strategic Plan. Implementation of the National Population for Sustainable Development. Nairobi: National Coordination Agency for Population Development.

Republic of Kenya. (2005). Sessional paper No.1. of 2005 Kenya Education Sector Support Programme. Nairobi: Government Printer.

Republic of Kenya. (2006). Ministry of Education Strategic plan 2006-2011. Nairobi: Government Printer.

Republic of Kenya. (2006). Sessional Paper No.55 of 2006 Financing of secondary Education in Kenya Costs and Options. Nairobi: Government Printer.

Republic of Kenya. (2008). Kenya's Economic Survey Highlight. Nairobi: Government Printer.

Republic of Kenya. (2010). Kenya's Economic Survey Highlight Report. Nairobi: Government Printer.

Republic of Kenya. (2010). National census and Population Statistics. Nairobi: Government Printer.

Republic of Kenya. (2011 a). Ministry of Education Quality Education for Development. Nairobi: Government Printer.

Republic of Kenya. (2011 b). Kenya's Economic Survey Highlight. Nairobi: Government Printer.

Republic of Kenya. (2012). Sessional Paper No...of 2012. A policy Framework for Education and Training. Reforming Education and Training in Kenya. Government of Kenya. Nairobi. Government Printer. http://www.vision2030.go.ke/cms/vds/Sessional_ Paper_July_5,_2012.pdf

Republic of Kenya. (2012). Vision and Mission of the Ministry Of Education. Nairobi: Government printer.

Republic of Kenya. (2013). Sessional Paper No. 14 of 2013. Kenya Basic Education Act. Nairobi. Government Printer.

Rosario M (2011). Enrolment rates in Philippine town and city schools before and after the social programme was implemented. Philippines Institute of Development studies.

Southern and Eastern African Consortium for Monitoring and Evaluation Quality (2012). Education in Zanzibar. http://www.sacmeq.org/education-zanzibar.htm.

Soi D, Barmao A \& Ngeno J K (2013). Influence of School Type on Girls' Attitudes towards Mathematics in Ainamoi Division, Kericho District, Kenya. Asian Journal of Social Sciences \& Humanities. Vol. 2: 2186-8492. 
South African Basic Education. (2011). Report on Dropout and Learner Retention Strategy Department of Basic Education. Portfolio Committee on Education. Republic of South Africa.

http://www.education.gov.za/LinkClick.aspx?fileti cket=jcSsYOrHcME\%3D\&tabid=358\&mid=1261.

Retrieved on $1^{\text {st }}$ march 2014 at 8:59.

State University. (2002 a). Criticism of Public Education - Inequality of Opportunity, Highly Bureaucratic Systems, Achievement-Based Outcomes, School Choice, Reform after Reform. StateUniversity.com

http://education.stateuniversity.com/pages/2341/ Public-Education-Criticism.html\#ixzz21kP3lpsL.

State University. (2002 b). School Dropouts - Extent of the Problem, Factors Associated with Early School Leaving, Dropout Prevention Programs and Their Effects - StateUniversity.com http://education.stateuniversity.com/pages/1921/ Dropouts-School.html\#ixzz1y3P8rOq3.

Suryahadi A \& Sambodho P (2013). Assessment of Policies to Improve Teacher Quality and Reduce Teacher Absenteeism. Jakarta. The SMERU Research Institute. http://www.smeru.or.id/report/workpaper/improv eteacherquality/.

Takashi Y \& Asankha P (2011). Impact of Universal Secondary Education Policy on Secondary School Enrolment in Uganda. Journal for Accounting Finance and Economics Vol. 1(1):1630.

Takashi Y \& Asankha P (2008). Impact of Universal Secondary Education in Uganda. Development Economics, Economics of Education. Kampala. Makerere University.

The Daily (2010). Trends in dropout rates and the labour market outcomes of young dropouts. Statistics Canada www.statcan.gc.ca.

The Standard Newspaper (2009, May 21 $\left.{ }^{\text {st }}\right)$. KCSE performance Analysis. The Standard Newspaper. Nairobi: Standard Media Group.p.10.

The Standard Newspaper (2012, March $1^{\text {st }}$ ). KCSE performance Analysis and Gender Parity Index. The Standard Newspaper. Nairobi: Standard Media Group.p.10

The Standard Newspaper (2014, March 21 ${ }^{\text {st }}$ ). Thirteen year old girl drop out of school due to pregnancy in Siaya District. Nairobi: Standard Media Group.p.2

UN. (2005).The Millennium Development Goals Report 2005. New York: UN http://unstats.un.org/unsd/mi/pdf/mdg\%20book.p df.

UNESCO. (2004 a). A comparison of primary school gross and net enrolment rates in sub- Saharan Africa. Paris: UNESCO.

UNESCO. (1971). Wastage in Education a world Problem. A study prepared for the International Bureau of Education. Paris: UNESCO.
UNESCO. (1992). Performance in sub- Saharan Africa between the boys and the girls. Paris: IIEP.

UNESCO. (2003). Global Education Digest shows Rapid Growth in Secondary Education Worldwide. Paris: UNESCO.

UNESCO. (2004 b). Indicators of wastage rates in Education. Institute of Statistics. IIEP Paris: http://www.unesco.org/iiep/.

UNESCO. (2004 c). The State of the Right to Education Worldwide Free to Free. Paris UNESCO. www.katrinatomaserki.com. Retrieved on $17^{\text {th }}$ June 2012 at $10: 30$ A.M.

UNESCO. (2006 a). Grade Repetition, International Policy Series; International Academy of Education. Paris. IIEP http://www.unesco.org/iiep/.

UNESCO. (2006 b). Principles and General Objectives of Education. International Bureau of Education: http://www.ibe.unesco.org sub saharan_africa/nigeria/nigeria.htm.

UNESCO. (2009 a). Education for All by 2015. Education International's Response to the Global Monitoring Report 2008. ie.org/docs/Retrieved on $26^{\text {th }}$ July 2012 at 7:30 pm

UNESCO. (2009 b). Education Indicators Technical Guidelines. UNESCO institute for Statistics. Paris: UNESCO.

UNESCO. (2009 c). The role of the higher Education Loans Board in Pro-poor management approaches to enhancing access to university education in Kenya. Paris:IIEP. unesco.org/cgi-bin/www.

UNESCO. (2009 d). Gender Equity in Education: Policy Guidelines for Implementation Aus AID Australian Government. ISBN 978-9980-86-1894 Department of Education, Papua New Guinea.

UNESCO. (2010 a). A study carried out in Africa on Enrolment rates after introduction of subsidized education. Paris: UNESCO.

UNESCO. (2010 b). Global Education Digest, Comparing Education Statistics across the World, Montreal. Paris: UNESCO.

UNESCO. (2011 b). Report on the Gender Initiative; gender Equality in Education, Employment \& entrepreneurship. Meeting of the OECD Council at Ministerial Level Paris 25-26 May, 2011. Paris: Organization for Economic Co-operation and Development .

UNESCO. (2011a). Gender Equality in Education. Looking Beyond Parity. An IIEP Evidence based Policy Forum. UNESCO Paris: IIEP.

UNESCO. (2012). Measuring Education Quality in Africa. UNESCO world Education Blog. Paris. UNESCO.

UNGEI. (2011).Gender Equality Assessment in Education. East Asia and Pacific Region. Bangkok: UNICEF.

UNHRC. (2012). Assessing the 2012 UN Human Rights Council Elections: One-Third of 
Candidates Unqualified for Membership. Bangkok: UNHRC.

UNICEF. (2009). Gender Equality in Education Snapshot 'Education for All mid Decade Assessment "East Asia and Pacific Regional Office. Bangkok: UNICEF. http://www.unicef.org/eapro/Gender_Snapshot_ web.pdf.

Woodhall M (2004). Analysis in Educational Planning Cost Benefit Analysis in Education. Paris: IIEP .UNESCO.

World Bank. (1980). Education Sector Policy Paper. Washington D.C: World Bank.

World Bank, (2008). Gender Equity in Junior and Senior Secondary Education in Sub- Saharan Africa. African Human Development Series working paper No.140. Washington D.C. www.directions.usp.ac.fj/collect/direct/index/ass oc/D770108.

World Bank. (2000 a). Education for All from Jomtiem to Dakar and Beyond. Word bank. Senegal
http://siteresources.worldbank.org/Education/Re sources/278200-1099079877269/5476641099079993288/efa_jomtien_dakar.pdf.

World Bank. (2000 b). World Declaration on Education for all and Framework for Action to meet the basic needs. Jomtiem: Thailand, World Bank.

World Bank. (2005). Educational Sector Strategy Update: Achieving Education For All Broadening our perspective, Maximizing our effectiveness. Washington D.C: World Bank.

World Bank. (2007). Primary school Education Programme in Cambodia. World Food Programme.http://www.foodsecurityatlas.org/kh $\mathrm{m} /$ country/education/primary-education. Retrieved on Sunday 24 $4^{\text {th }}$ June 2012 at 7:53 pm. World Bank. (2011). Education in Sub Saharan Africa. Secondary School Education in Africa http://go.worldbank.org/VKSZDOAZJ0.Retrieved on Sunday 17th June 2012 at 12:15 pm. 